\title{
Statistical Significance of Reduction in Load Bearing Properties of Crude Oil Contaminated Soil in Kwale, Niger Delta
}

\author{
Iloeje Amechi Francis ${ }^{1}$ and Okoye Victor ${ }^{2}$ \\ 1. Department of Architecture, Enugu State University of Science and Technology, Enugu 400261, Nigeria \\ 2. Department of Business Administration and Management, Institute of Management and Technology, Enugu 1293, Nigeria
}

\begin{abstract}
The Niger Delta has experienced tons of crude oil spill within their environment over the years and its impact on the environment is quite lethal. The soil is a major recipient of this spilled crude. When contaminated with crude oil, the load bearing capacity is consequently affected. This study aimed at providing a statistical evidence to prove that the impact of crude oil contamination on the soil's bearing capacity is significant. Four samples of uncontaminated soil of Kwale were collected and analyzed for their load bearing properties: cohesion $(c)$, angle of internal friction $\left(\theta^{\circ}\right)$ and bulk density $(\gamma)$. These soil samples were polluted with crude oil in levels of 5\%,10\%, 15\% and $20 \%$ and compared with intact soil. A consistent reduction was observed in the bearing capacity as the crude oil level increased. Using the SPSS (statistically package for social sciences), the significance was tested at the various contamination levels at a 5\% confidence level and the result showed significance at $15 \%$ and $20 \%$ levels with calculated $P$-values of 0.038 and 0.035 respectively for both the square and strip foundation footings.
\end{abstract}

Key words: Bearing capacity, soil, contamination, crude oil, environment.

\section{Introduction}

The frequency of oil spill has been on a steady increase in most of the oil producing communities in the Niger Delta region of Nigeria. The impact is lethal and multidimensional. The soil bearing capacity which is the ability of the soil to support structure load is the first to receive the brunt of this phenomenon when it occurs. Crude oil, when spilled, moves both vertically, by gravity and horizontally, as it flows and spreads throughout the length and depth of the receiving soil, destroying the vegetal, terrestrial and aquatic environments. According to Pamukcu and Hijazi [1] the spillage of hydrocarbon liquid moves downward under gravity partially saturating the soil in its path towards groundwater level. Generally hydrocarbon is more viscous than water, therefore it relatively moves slower within the groundwater body Zulfahmi et al. [2].

Corresponding author: Iloeje Amechi Francis, Ph.D., research fields: environmental management/architecture. E-mail: get2frankfast@gmail.com.
Several studies investigating the effects of hydrocarbon on the engineering properties of the soil have been carried out. Evgin and Das [3], using triaxial tests examined the effects of crude oil on contaminated clean sands, and Shin and Das [4] also studied the effect of crude oil on load bearing capacity of sand at oil contents ranging from $0 \%$ to $6 \%$. Khamehchiyan et al. [5] investigated the effects of crude oil contamination on geotechnical properties of clayey and sandy soils. Aiban [6] examined the effects of temperature on engineering properties of oil contaminated sand in Kuwait, while Oku [7] studied the spatial variation of soil properties on oil spillage sites in the Niger Delta, Nigeria. All these studies agreed on the reduction of soil strength due to crude oil, but none explored whether this reduction in soil strength is statistically significant.

This study, therefore, aimed at investigating the statistical significance of the reduction in the load bearing properties of the Kwale soil due to crude oil 
contamination.

\section{Material and Methods}

\subsection{Study Location}

Kwale is one of the major towns in Ndokwa West LGA (Local Government Area) of Delta State and the headquarters of the LGA, Ndokwa West. A large expanse of the land has been used up by the oil field with several oil wells. This made the neighboring communities highly vulnerable to spills. The area experiences double rainfall peaks in June/July and September/October, with an average temperature of 30 ${ }^{\circ} \mathrm{C}$ [8]. The heavy precipitation assists in the downward movement of oil to the ground water table.

\subsection{Experimental Procedure and Design}

To generate the data set for this study, four soil samples were collected from four boreholes in the study area and analyzed through appropriate laboratory tests. These samples were collected using the hand auger. Triaxial tests were conducted on the remolded soil samples before and after contamination. The bulk density, height, diameter and initial moisture content of the specimen were determined. The specimen was then enclosed with rubber membrane and mounted on the base of the triaxial cell with solid end caps placed on either ends. With the triaxial cell placed in the compression machine, hydrostatic pressure as required was applied and kept constant till the end of the experiment. The test was repeated on two identical specimens with increasing pressure. Mohr circles were drawn for each test at failure and a common tangent drawn to the Mohr circles gave the failure envelope from where the parameters cohesion $(c)$ and angle of internal friction $\left(\theta^{\circ}\right)$ were determined. This was done for all the four borehole samples and the results presented in Table 1.

\subsection{Hypothesis}

The hypothesis adopted in this study, $H_{o}$ is that the reduction due to crude oil spill on the bearing capacity of crude oil contaminated soil is not significant.

Table 1 Summary of triaxial test results.

\begin{tabular}{|c|c|c|c|c|c|c|c|}
\hline \multirow{2}{*}{$\begin{array}{l}\text { Bore hole } \\
\text { number }\end{array}$} & \multirow{2}{*}{ Depth } & \multirow{2}{*}{ Percentage oil (\%) } & \multirow{2}{*}{$\begin{array}{l}\text { Bulk density } \\
\left(\mathrm{g} / \mathrm{cm}^{3}\right)\end{array}$} & \multirow{2}{*}{$\begin{array}{l}\text { Cohesion } \\
\left(\mathrm{kN} / \mathrm{m}^{2}\right)\end{array}$} & \multirow{2}{*}{$\begin{array}{l}\text { Angle of internal } \\
\text { friction }\left(\theta^{\circ}\right)\end{array}$} & \multicolumn{2}{|c|}{ Bearing capacity $\left(\mathrm{kN} / \mathrm{m}^{2}\right)$} \\
\hline & & & & & & Square footing & Strip footing \\
\hline \multirow{5}{*}{1} & 1.5 & 0 & 2.07 & 84 & 32 & $1,154.97$ & 975.95 \\
\hline & 1.5 & 5 & 2.11 & 23 & 5 & 88.18 & 75.82 \\
\hline & 1.5 & 10 & 2.10 & 14 & 3 & 59.23 & 51.74 \\
\hline & 1.5 & 15 & 2.11 & 11 & 2 & $4,959.00$ & 43.70 \\
\hline & 1.5 & 20 & 2.10 & 10 & 2 & 46.30 & 40.95 \\
\hline \multirow{5}{*}{2} & 1.5 & 0 & 2.09 & 57 & 20 & 362.24 & 308.50 \\
\hline & 1.5 & 5 & 2.07 & 45 & 15 & 236.49 & 201.58 \\
\hline & 1.5 & 10 & 2.11 & 33 & 10 & 146.04 & 124.94 \\
\hline & 1.5 & 15 & 2.09 & 113 & 2 & 55.88 & 48.88 \\
\hline & 1.5 & 20 & 2.10 & 8 & 2 & 39.87 & 35.59 \\
\hline \multirow{5}{*}{3} & 1.5 & 0 & 2.10 & 76 & 27 & 777.70 & 662.40 \\
\hline & 1.5 & 5 & 2.09 & 60 & 22 & 482.93 & 412.02 \\
\hline & 1.5 & 10 & 2.10 & 24 & 8 & 111.39 & 96.05 \\
\hline & 1.5 & 15 & 2.10 & 18 & 7 & 88.35 & 76.85 \\
\hline & 1.5 & 20 & 2.10 & 18 & 6 & 88.35 & 76.85 \\
\hline \multirow{5}{*}{4} & 1.5 & 0 & 2.08 & 68 & 23 & 539.50 & 459.11 \\
\hline & 1.5 & 5 & 2.11 & 52 & 18 & 334.30 & 285.28 \\
\hline & 1.5 & 10 & 2.11 & 38 & 13 & 204.55 & 174.96 \\
\hline & 1.5 & 15 & 2.09 & 26 & 9 & 118.98 & 102.36 \\
\hline & 1.5 & 20 & 2.10 & 23 & 8 & 107.55 & 92.85 \\
\hline
\end{tabular}


The objective of this hypothesis was to determine whether the reduction observed in the bearing capacity of crude oil contaminated soil of Kwale, is statistically significant. To test this hypothesis, paired sample $t$-test was used and the results presented in Tables $2 \mathrm{a}$ and $2 \mathrm{~b}$.

The bearing capacity values for square and strip footings, for each borehole sample were calculated using Terzaghi's bearing capacity theory with the relevant bearing capacity factors as follows:

for square footing:

$$
q_{u}=1.3 c N_{c}+\gamma D_{f} N_{q}+0.4 \gamma B N \gamma
$$

for strip footing:

$$
q_{u}=c N_{c}+\gamma D_{f} N_{q}+0.5 B \gamma N \gamma
$$

where, $N_{c}, N_{q}$ and $N \gamma$ are bearing capacity factors assumed by Terzaghi, and $c$ is cohesion, $D_{f}$ is foundation depth, $B$ is foundation width, $\gamma$ is bulk density

\section{Results and Discussion}

From Table 1 for borehole sample 1, at $0 \%$ contamination (control), the bearing capacities were $1,154.97 \mathrm{kN} / \mathrm{m}^{2}$ and $975.95 \mathrm{kN} / \mathrm{m}^{2}$ for square and strip footings respectively. At 5\% contamination (observed) they dropped drastically to $88.18 \mathrm{kN} / \mathrm{m}^{2}$ and 75.82 $\mathrm{kN} / \mathrm{m}^{2}$, respectively. The bearing capacity at $10 \%, 15 \%$ and $20 \%$ (observed) where recorded as $59.23 \mathrm{kN} / \mathrm{m}^{2}$ and $51.74 \mathrm{kN} / \mathrm{m}^{2}, 49.59 \mathrm{kN} / \mathrm{m}^{2}$ and $43.7 \mathrm{kN} / \mathrm{m}^{2}$, and $46.30 \mathrm{kN} / \mathrm{m}^{2}$ and $40.95 \mathrm{kN} / \mathrm{m}^{2}$ for both square and strip footings, respectively. Similarly for the other three borehole samples the bearing capacity values were as recorded in Table 1.

Table 3 presented the summary of the mean values of the bearing capacity of Kwale soil at the various contamination levels. It was clearly evident that there was a consistent reduction in the values from 708. 603 $\mathrm{kN} / \mathrm{m}^{2}$ and $601.49 \mathrm{kN} / \mathrm{m}^{2}$ down to $70.518 \mathrm{kN} / \mathrm{m}^{2}$ and $61.56 \mathrm{kN} / \mathrm{m}^{2}$ at $0 \%$ and $20 \%$ contamination levels for the square and strip footings respectively. These results were used for the statistical analysis employing the SPSS (Statistically Package for Social Sciences).

From the statistics in Tables 2a (i-viii), the tests were conducted on the paired mean values of the bearing capacity for square and strip footings at $0 \%$ and $5 \%, 0 \%$ and $10 \%, 0 \%$ and $15 \%, 0 \%$ and $20 \%$ for all the borehole samples. The paired sample statistics in Table $2 \mathrm{a}$ (i) showed the paired bearing capacity at $0 \%$ and $5 \%$, whose mean values were $708.603 \mathrm{kN} / \mathrm{m}^{2}$ and 285.475 $\mathrm{kN} / \mathrm{m}^{2}$. $\mathrm{N}$ in column three indicated the number of samples which is 4 . The standard deviation and standard error were presented in columns 4 and 5 . Table $2 \mathrm{~b}$ (i) presented the actual statistical test of the paired samples. At $95 \%$ confidence interval the level of significance was 0.147 on a two tailed test. Also in Table $2 \mathrm{a}$ (ii), the bearing capacity at $0 \%$ was paired against that at $10 \%\left(708.603 \mathrm{kN} / \mathrm{m}^{2}\right.$ against 130.303 $\mathrm{kN} / \mathrm{m}^{2}$ ). The result of the test showed a significance level of 0.061 shown in Table $2 b$ (ii). In the same vein, in Tables 2a (iii-iv) and $2 b$ (iii-iv), the results of the paired tests were 0.038 and 0.035 for $0 \% / 15 \%$ and $0 \% / 20 \%$ pairs. The results of the hypothesis showed a significance level of 0.038 and 0.035 at $15 \%$ and $20 \%$ contamination levels respectively indicating statistical significance. These results recorded in Tables $2 \mathrm{a}$ and $2 b$ (i-iv) were for square footing.

The strip footing results were presented in Tables $2 \mathrm{a}$ and $2 \mathrm{~b}$ (v-viii). Similar tests were conducted and the results showed that at $15 \%$ and $20 \%$ contamination levels the test of significance indicated 0.038 and 0.035 respectively while at $5 \%$ and $10 \%$ the levels of significance were 0.147 and 0.061 , respectively.

About decision rule, the null hypothesis is accepted if the calculated value is greater than 0.05 $(P>0.05)$, otherwise it is rejected and the alternative, which is, the research hypothesis, $\mathrm{H}_{1}$ is accepted. The result of the only null hypothesis showed that the calculated $P$-values at $5 \%$ and $10 \%$ contamination levels were more than $0.05(P<0.05)$. The null hypothesis was therefore accepted at that point while the alternative which is the research hypothesis was rejected. Furthermore at $15 \%$ and $20 \%$ contamination levels, the calculated $P$-values of 0.038 and 0.035 for both the square and strip footings respectively were 
Tables 2 Paired sample $t$-test (a and b).

\begin{tabular}{|c|c|c|c|c|}
\hline \multicolumn{5}{|c|}{ (a) Paired sample statistics square footing (i) } \\
\hline Pairs & Mean & $\mathrm{N}$ (number of samples) & Standard deviation & Standard error mean \\
\hline Pair $1 \mathrm{BC}_{\text {square }} 0 \%$ & 708.6030 & 4 & 342.82213 & 171.41107 \\
\hline Pair $1 \mathrm{BC}_{\text {square }} 5 \%$ & 285.4750 & 4 & 166.02932 & 83.01466 \\
\hline \multicolumn{5}{|c|}{\begin{tabular}{|l|} 
Paired sample statistics square footing (ii) \\
\end{tabular}} \\
\hline Pair $2 \mathrm{BC}_{\text {square }} 0 \%$ & 708.6030 & 4 & 342.82213 & 171.41107 \\
\hline Pair $2 \mathrm{BC}_{\text {square }} 10 \%$ & 130.3025 & 4 & 61.01733 & 30.50866 \\
\hline \multicolumn{5}{|c|}{ Paired sample statistics square footing (iii) } \\
\hline Pair $3 \mathrm{BC}_{\text {square }} 0 \%$ & 708.6030 & 4 & 342.82213 & 171.41107 \\
\hline Pair $3 \mathrm{BC}_{\text {square }} 15 \%$ & 78.2000 & 4 & 32.05592 & 16.02796 \\
\hline \multicolumn{5}{|c|}{ Paired sample statistics square footing (iv) } \\
\hline Pair $4 \mathrm{BC}_{\text {square }} 0 \%$ & 708.6030 & 4 & 342.82213 & 171.41107 \\
\hline Pair $4 \mathrm{BC}_{\text {square }} 20 \%$ & 70.5175 & 4 & 32.73714 & 16.36857 \\
\hline \multicolumn{5}{|c|}{ Paired sample statistics strip footing (v) } \\
\hline Pairs & Mean & $\mathrm{N}$ & Standard deviation & Standard error mean \\
\hline Pair $1 \mathrm{BC}_{\text {square }} 0 \%$ & 601.4900 & 4 & 288.70142 & 144.35071 \\
\hline Pair $1 \mathrm{BC}_{\text {square }} 5 \%$ & 243.6750 & 4 & 141.44293 & 70.72146 \\
\hline \multicolumn{5}{|c|}{ Paired sample statistics strip footing (vi) } \\
\hline Pair $2 \mathrm{BC}_{\text {square }} 0 \%$ & 601.4900 & 4 & 288.70142 & 144.35071 \\
\hline Pair $2 \mathrm{BC}_{\text {square }} 10 \%$ & 111.9225 & 4 & 51.69478 & 25.84739 \\
\hline \multicolumn{5}{|c|}{ Paired sample statistics strip footing (vii) } \\
\hline Pair $3 \mathrm{BC}_{\text {square }} 0 \%$ & 601.4900 & 4 & 288.70142 & 144.35071 \\
\hline Pair $3 \mathrm{BC}_{\text {square }} 15 \%$ & 67.9475 & 4 & 27.17220 & 13.58610 \\
\hline \multicolumn{5}{|c|}{ Paired sample statistics strip footing (viii) } \\
\hline Pair $4 \mathrm{BC}_{\text {square }} 0 \%$ & 601.4900 & 4 & 288.70142 & 144.35071 \\
\hline Pair $4 \mathrm{BC}_{\text {square }} 20 \%$ & 61.5600 & 4 & 27.76125 & 13.88063 \\
\hline
\end{tabular}

(b) paired samples test (i) square footing

\begin{tabular}{|c|c|c|c|c|c|c|c|c|}
\hline & \multicolumn{5}{|c|}{ Paired differences } & & \multirow{3}{*}{ df } & \multirow{3}{*}{$\begin{array}{l}\text { Significance } \\
\text { (2-tailed) }\end{array}$} \\
\hline & \multirow{2}{*}{ Mean } & \multirow{2}{*}{ Std. deviation } & \multirow{2}{*}{ Std. error mean } & \multicolumn{2}{|c|}{$95 \%$ confidence interval of the difference } & & & \\
\hline & & & & Lower & Upper & & & \\
\hline Pair 1 & 423.12750 & 434.62736 & 217.31368 & -268.46162 & $1,114.71662$ & 1.947 & 3 & 0.147 \\
\hline \multicolumn{9}{|c|}{ Paired Samples Test (ii) } \\
\hline & \multicolumn{5}{|c|}{ Paired differences } & \multirow{3}{*}{$t$} & \multirow{3}{*}{ df } & \multirow{3}{*}{$\begin{array}{l}\text { Significance } \\
\text { (2-tailed) }\end{array}$} \\
\hline & \multirow{2}{*}{ Mean } & \multirow{2}{*}{ Std. deviation } & \multirow{2}{*}{ Std. error mean } & \multicolumn{2}{|c|}{$95 \%$ confidence interval of the difference } & & & \\
\hline & & & & Lower & Upper & & & \\
\hline Pair 2 & 578.30000 & 394.04972 & 197.02486 & -48.72104 & $1,205.32104$ & 2.935 & 3 & 0.061 \\
\hline \multicolumn{9}{|c|}{ Paired samples test (iii) } \\
\hline & \multicolumn{5}{|c|}{ Paired differences } & & & \\
\hline & \multirow{2}{*}{ Mean } & \multirow{2}{*}{ Std. deviation } & \multirow{2}{*}{ Std. error mean } & \multicolumn{2}{|c|}{$95 \%$ confidence interval of the difference } & \multirow{2}{*}{$t$} & \multirow{2}{*}{ df } & \multirow{2}{*}{$\begin{array}{l}\text { Significance } \\
\text { (2-tailed) }\end{array}$} \\
\hline & & & & Lower & Upper & & & \\
\hline Pair 3 & 630.40250 & 355.02706 & 177.51353 & 65.47522 & $1,195.32978$ & 3.551 & 3 & 0.038 \\
\hline \multicolumn{9}{|c|}{ Paired Samples Test (iv) } \\
\hline & \multicolumn{5}{|c|}{ Paired differences } & & & \\
\hline & Mean & Std. deviation & Std. error mean & \multicolumn{2}{|c|}{$95 \%$ confidence interval of the difference } & $t$ & df & $\begin{array}{l}\text { Significance } \\
\text { (2-tailed) }\end{array}$ \\
\hline & & & & Lower & Upper & & & \\
\hline Pair 4 & 638.08500 & 349.40232 & 174.70116 & 82.10794 & $1,194.06206$ & 3.652 & 3 & 0.035 \\
\hline
\end{tabular}




\begin{tabular}{|c|c|c|c|c|c|c|c|c|}
\hline \multicolumn{9}{|c|}{ (b) Paired samples test (v) strip footing } \\
\hline & \multicolumn{5}{|c|}{ Paired differences } & \multirow{3}{*}{$t$} & \multirow{3}{*}{ df } & \multirow{3}{*}{$\begin{array}{l}\text { Significance } \\
\text { (2-tailed) }\end{array}$} \\
\hline & \multirow{2}{*}{ Mean } & \multirow{2}{*}{ Std. deviation } & \multirow{2}{*}{ Std. error mean } & \multicolumn{2}{|c|}{$95 \%$ confidence interval of the difference } & & & \\
\hline & & & & Lower & Upper & & & \\
\hline Pair 1 & 357.81500 & 366.26339 & 183.13170 & -224.99179 & 940.62179 & 1.947 & 3 & 0.146 \\
\hline \multicolumn{9}{|c|}{ Paired Samples Test (vi) } \\
\hline & \multicolumn{5}{|c|}{ Paired differences } & \multirow{3}{*}{$t$} & \multirow{3}{*}{ df } & \multirow{3}{*}{$\begin{array}{l}\text { Significance } \\
\text { (2-tailed }\end{array}$} \\
\hline & \multirow{2}{*}{ Mean } & \multirow{2}{*}{ Std. deviation } & \multirow{2}{*}{ Std. error mean } & \multicolumn{2}{|c|}{$95 \%$ confidence interval of the difference } & & & \\
\hline & & & & Lower & Upper & & & \\
\hline Pair 2 & 489.56750 & 331.98725 & 165.99362 & -38.69829 & $1,017.83329$ & 2.949 & 3 & 0.060 \\
\hline \multicolumn{9}{|c|}{ Paired samples test (vii) } \\
\hline & \multicolumn{5}{|c|}{ Paired differences } & & & \\
\hline & \multirow{2}{*}{ Mean } & \multirow{2}{*}{ Std. deviation } & \multirow{2}{*}{ Std. error mean } & \multicolumn{2}{|c|}{$95 \%$ confidence interval of the difference } & \multirow{2}{*}{$t$} & \multirow{2}{*}{ df } & \multirow{2}{*}{$\begin{array}{l}\text { Significance } \\
\text { (2-tailed) }\end{array}$} \\
\hline & & & & Lower & Upper & & & \\
\hline Pair 3 & 533.54250 & 298.86540 & 149.43270 & 57.98096 & $1,009.10404$ & 3.570 & 3 & 0.038 \\
\hline \multicolumn{9}{|c|}{ Paired samples test (viii) } \\
\hline & \multicolumn{5}{|c|}{ Paired differences } & & & \\
\hline & Mean & Std. deviation & Std. error mean & \multicolumn{2}{|c|}{$95 \%$ confidence interval of the difference } & $t$ & df & \begin{tabular}{|l|}
$\begin{array}{l}\text { Significance } \\
\text { (2-tailed) }\end{array}$ \\
\end{tabular} \\
\hline & & & & Lower & Upper & & & \\
\hline Pair 4 & 539.93000 & 294.17820 & 147.08910 & 71.82684 & $1,008.03316$ & 3.671 & 3 & 0.035 \\
\hline
\end{tabular}

Table 3 Mean bearing capacity values.

\begin{tabular}{llll}
\hline \multirow{2}{*}{$\mathrm{S} / \mathrm{N}$} & \multirow{2}{*}{$\begin{array}{c}\text { Percentage of oil } \\
\text { contamination }\end{array}$} & \multicolumn{2}{c}{ Bearing capacity $\left(\mathrm{kN} / \mathrm{m}^{2}\right)$} \\
\cline { 3 - 4 } & 0 & Square footing & Strip footing \\
\hline 1 & 5 & 708.603 & 601.490 \\
2 & 285.475 & 243.683 \\
3 & 10 & 130.303 & 111.923 \\
4 & 15 & 78.200 & 67.948 \\
5 & 20 & 70.518 & 61.560 \\
\hline
\end{tabular}

less than $0.05(P<0.05)$, the null hypothesis was rejected while the research hypothesis was accepted. This suggests therefore that at higher crude oil pollution levels the impact is significantly high. This finding is consistent with the findings of Shin and Das [8] which indicated that the load bearing capacity of the soil drops significantly with increase in crude oil content.

\section{Conclusion and Recommendations}

From the study, it became evident that statistically speaking, the impact of crude oil spill on the soil is significant to cause appreciable damage to the soils load bearing properties in Kwale, an oil producing community, at beyond $10 \%$ contamination. It therefore becomes imperative for the oil operators to apply every reasonable means to drastically reduce if not completely eliminate spillage in the environment especially within the host communities. Furthermore, deliberate policies and enabling laws ought to be enacted to specifically address spillage issues, and implementation pursued vigorously to mitigate impacts.

\section{References}

[1] S. Pamukcu, H. Hijazi, Grouting/Soil Improvement and Geosynthetics, Grouting/Soil Improvement and Geosynthetics, New York, 1992.

[2] A.R. Zulfahmi, H. Umar, R.T. Mohd, S.I. Norsheila, A. Noorulakma, Influence of oil contamination on geotechnical properties of basaltic residual soil, American Journal of Applied Sciences 7 (7) (2011) 954-961.

[3] E. Evgin, B.M. Das, Mechanical behavior of oil contaminated sand, environmental geotechnology, in: Proceedings of Mediterranean Conference, Netherlands, 1992, pp. 101-108.

[4] E.C. Shin, M.B. Das, Bearing capacity of unsaturated oil-contaminated sand, International Journal of Offshore and Polar Engineering 11 (3) (2001) 220-226.

[5] M. Khamehchiyan, A.H. Charkhabi, M. Tajik, Effects of crude oil contamination on geotechnical properties of clayed and sandy soils, Journal of Engineering Geotechnology Science 89 (3-4) (2006) 220-229. 


\section{Oil Contaminated Soil in Kwale, Niger Delta}

[6] A.S. Aiban, The effect of temperature on the engineering properties of oil-contaminated sand, Environment International 24 (1/2) (1997) 153-161.

[7] H.B. Oku, Spatial variation of soil properties on oil spillage sites in the Niger Delta, Nigeria, Nigerian Journal of Agriculture, Food and Environment 7 (2) (2011) 94-99.

[8] Ndokwa-west Web Site, en.wikipedia.org/wiki/ Ndokwa-west (accessed Feb. 15, 2013). 